\title{
Nitrogen leaching losses from forests in New Zealand
}

Murray Davis

\begin{abstract}
Regional governing organisations in New Zealand are developing new policies to assess and manage the effects of land use intensification on water quality. Such policies require an assessment to be made of potential nitrogen leaching losses from different land uses, particularly where land use may be becoming more intensive. This review compiles the information on nitrogen concentrations and fluxes in stream and soil water drainage from indigenous and planted forests in New Zealand. Nitrogen concentrations and losses in streams from undisturbed indigenous forests and from planted forests established on land that has not been developed for agriculture are low. Nitrogen concentrations and losses in streams draining forests established on pasture land are commonly higher than in streams from indigenous forests and from forests planted on non-agricultural land, however most of the values for planted forests on pasture land were influenced by high volcanic nitrogen inputs. The impact of afforestation of pasture land on nitrogen leaching is described, as are the effects of planted forest management practices including fertilisation, harvesting and herbicide use. Nitrogen leaching is generally not greatly affected by forest management practices, however fertilisation can cause large leaching losses in coastal sand forests. While nitrogen leaching from planted forests is normally less than from other major land uses, there are key times during the forest rotation when nitrogen leaching may occur, particularly in forests planted on coastal sands or pasture land. It is advantageous to minimise leaching at these key stages to limit adverse effects on the environment and maintain nitrogen in the soil for the benefit of crop nutrition. Measures to reduce nitrogen leaching losses in forests are discussed, as are practices to minimise nitrogen leaching of forest plantings in catchments with high nitrogen soils, where forests may be planted specifically to reduce nitrogen loss to sensitive waterways.
\end{abstract}

Keywords: Leaching; Nitrogen; Nitrate; Soil water; Stream water; Management impacts

\section{Review}

The nitrogen $(\mathrm{N})$ cycle in temperate forests is characterised by an almost closed internal cycle between the vegetation and the pool of $\mathrm{N}$ in soil organic matter. Important processes are above and below ground litter production, decomposition, mineralisation (including nitrification), immobilisation, and plant uptake (Gundersen et al. 2006). Except where losses occur as a result of fire, or removal of $\mathrm{N}$ in wood products, losses mainly occur as dissolved $\mathrm{N}$ in seepage water in the form of ammonium and nitrate ions, and dissolved organic $\mathrm{N}$ (DON). Nitrite ions are formed as a step in the nitrification process, but are rapidly oxidised to nitrate in most soils. The conversion of ammonium to nitrite and then to nitrate is mediated by specific soil bacteria and the

Correspondence: murray.davis@scionresearch.com Scion, P.O. Box 29237, Christchurch, New Zealand rate is sensitive to soil conditions. The maximum nitrification rate occurs when the soil moisture content is around field capacity, the soil $\mathrm{pH}$ is between 4.5 and 7.5 and the soil temperature is between 25 and $30{ }^{\circ} \mathrm{C}$ (Cameron et al. 2013). Although nitrification occurs more slowly outside these optima, nitrate formation in indigenous and planted forest soils may be limited by low soil moisture content, low temperature and low soil $\mathrm{pH}$. Losses to the atmosphere may also occur in poorly drained soils or riparian zones where nitrate is denitrified to $\mathrm{N}_{2}$ or other gaseous forms. Losses in drainage water in pristine systems are almost entirely in the form of organic N (Hedin et al. 1995; Perakis and Hedin, 2002), elsewhere nitrate, which is highly mobile in dominantly negatively charged soils, is usually the main form lost through leaching. Soils in the tropics, however often carry positive charges, and nitrate is adsorbed onto the

\section{穴}


surfaces of soil particles, resulting in significant delays in leaching (Di and Cameron 2002).

Internationally, nitrate leaching losses from forest systems are generally lower than from other land uses (Di and Cameron 2002), and New Zealand studies indicate that $\mathrm{N}$ leaching losses from planted forests follow this trend (Elliot et al. 2005; Hamilton 2005; Larned et al. 2004). However, application of $\mathrm{N}$ fertiliser and other management practices have the potential to increase leaching losses of nitrate and other forms of $\mathrm{N}$ from forests (Binkley et al. 1999; Gundersen et al. 2006). Nitrogen leaching losses into rivers and lakes can cause eutrophication resulting in excessive growth of aquatic weeds and algae, which can reduce fish populations and the recreational value of the water. Further, contamination of drinking water supplies by nitrate can cause health risks (Cameron et al. 2013). The maximum acceptable value for nitrate in drinking water in New Zealand is $50 \mathrm{mg} \mathrm{L}^{-1}$ which equals $11.3 \mathrm{mg}$ nitrate- $\mathrm{N} \mathrm{L}^{-1}$ (Ministry of Health 2008).

In New Zealand, regional governing organisations are developing new policies to assess and manage the effects of land use intensification on water quality (e.g. Waikato Regional Council 2012). Such policies require an assessment to be made of potential $\mathrm{N}$ leaching losses from different land uses, particularly where land use may be becoming more intensive. This paper compiles and synthesises the information on $\mathrm{N}$ concentrations and fluxes in stream and soil-water drainage from indigenous and planted forests in New Zealand with the objective of providing managers with a knowledge base to allow appropriate land use decisions to be made regarding water quality. The two types of forest-soil water that were considered, were water draining from below the majority of tree roots (hereafter referred to as water draining from the lower root zone) and water in small forest streams. Forest-soil water draining from the lower root zone was assessed/measured using gravity or tension lysimeters. Water draining from the lower root zone directly reflects the dissolved $\mathrm{N}$ response of the plant-soil interactions in the $\mathrm{N}$ cycle, whereas stream water reflects additional $\mathrm{N}$ processes such as denitrification in the riparian zone and/or in-stream $\mathrm{N}$ conversion (e.g. Cooper et al. 1987, Cooper and Thomsen 1988). In-stream processes mainly consume dissolved $\mathrm{N}$, and thus lower concentrations of $\mathrm{N}$ are normally found in stream water than in water draining beneath the root zone (Gundersen et al. 2006).

Indigenous forests in New Zealand cover about 8 million ha or $30 \%$ of the land area (Ministry for the Environment (MfE) 2010) and have the characteristics of evergreen rain-forest. At lower elevations, indigenous forests are dominated by tall conifers (predominantly Podocarpus species), by broad-leaved evergreen trees, or by mixtures in which the conifers form an open overstorey to the main canopy of broad-leaved trees. In colder or drier localities, beeches (Nothofagus species) dominate extensive forests of relatively simple structure to the exclusion of other species (Wardle 1991). Pinus radiata D.Don (radiata pine) is the dominant planted forest species, covering $90 \%$ of the 1.7 million ha afforested area, with Pseudotsuga menziesii ([Mirb.] Franco) (Douglas-fir) making up much of the remainder (Ministry of Primary lindustries (MPI) 2012). The forests, both indigenous and planted, occur on an array of soils. The most extensive are Brown Soils, which cover $43 \%$ of New Zealand and occur where summer drought is uncommon and the soils are not waterlogged in winter (Molloy 1998). Other important soils include Podzols in high rainfall areas, Pallic Soils in summer-dry eastern areas and Allophanic and Pumice Soils which occur predominantly in volcanic areas (Molloy 1998). Characteristics associated with New Zealand Soil Orders are described in Hewitt (1992). New Zealand lies in the mid-latitude zone of the southern hemisphere and has a temperate climate. Rainfall is highest in the west of the country with annual precipitation exceeding $10000 \mathrm{~mm}$ on western mountain ranges, declining to $500-700 \mathrm{~mm}$ along the eastern coast (Wardle 1991). Rainfall is relatively evenly distributed through the year, but eastern areas are dry in summer.

\section{Nitrogen leaching from indigenous forests Nitrogen in stream water}

Streams draining undisturbed indigenous forest not influenced by atmospheric $\mathrm{N}$ inputs from nearby animal agriculture or volcanic sources contain uniformly low nitrate concentrations (Additional file 1: Table S1). Concentrations of nitrate- $\mathrm{N}$ in streams draining both small ( $<5$ ha) and larger catchments in undisturbed beechpodocarp-hardwood forest of the West Coast and Nelson regions range between zero and $0.05 \mathrm{mg} \mathrm{N} \mathrm{L}^{-1}$ (Neary et al. 1978, Mosley and Rowe 1981, Fahey and Jackson 1997). Low concentrations were also reported by Stenzel and Herrmann (1990) for 18 small streams draining indigenous forest and three streams draining manuka shrubland in the north or west of the South Island. More recently, a nationwide survey of 97 first order streams draining undisturbed indigenous forest revealed very low (median $=0.007 \mathrm{mg} \mathrm{N} \mathrm{L}^{-1}$ ) concentrations of nitrate-N (McGroddy et al. 2008).

Streams draining indigenous forest with adjacent animal agriculture tend to have higher concentrations of nitrate-N (Additional file 1: Table S1). Stenzel and Hermann (1990) found concentrations of 0.17 to $0.46 \mathrm{mg} \mathrm{N} \mathrm{L}^{-1}$ in three South Island east-coast peninsular streams from indigenous forest adjoining farmland, while Quinn and Stroud (2002) reported concentrations 
of 0.1-0.12 $\mathrm{mg} \mathrm{N} \mathrm{L}^{-1}$ in two streams draining podocarp/ hardwood forest at the Whatawhata Research Centre in the Waikato region. Quinn et al. (1997) had earlier reported lower concentrations $\left(0.015 \mathrm{mg} \mathrm{N} \mathrm{L}^{-1}\right)$ for five streams from podocarp/hardwood forest in the same area. The lower values may reflect sampling in a restricted period (November) when in-stream removal processes are particularly effective (Quinn and Stroud 2002). A national survey of lowland rivers (where indigenous forests were the dominant, but not necessarily the only land use) found mean oxidised $\mathrm{N}$ (nitrate + nitrite) concentrations of $0.21 \mathrm{mg} \mathrm{N} \mathrm{L}^{-1}$ suggesting an agricultural influence (Larned et al. 2004). Several studies have found consistently higher concentrations of nitrate- $\mathrm{N}\left(0.7-0.95 \mathrm{mg} \mathrm{N} \mathrm{L}^{-1}\right)$ in a stream draining podocarp/hardwood forest in the Purukohukohu experimental catchment area in the Bay of Plenty (Cooper et al. 1987, Cooper and Thomsen 1998, Parfitt et al. 2002 \& 2003b). While this forest adjoins farmland, the higher concentrations probably reflect atmospheric inputs of 3$6 \mathrm{~kg} \mathrm{~N} \mathrm{ha}^{-1} \mathrm{yr}^{-1}$ from volcanic sources in the area (Parfitt et al. 2002).

Ammonium-N and DON concentrations in streams draining indigenous forests range between 0.002 and 0.085 , and 0.02 and $0.296 \mathrm{mg} \mathrm{N} \mathrm{L}^{-1}$ respectively (Additional file 1: Table S1). Values for both were highest in streams influenced by inputs from volcanic or agricultural sources at the Purukohukohu and Whatawhata catchments respectively (Cooper and Thomsen 1988, Quinn and Stroud 2002). In other streams, ammonium$\mathrm{N}$ concentrations did not exceed $0.04 \mathrm{mg} \mathrm{N} \mathrm{L}^{-1}$ while DON concentrations did not exceed $0.06 \mathrm{mg} \mathrm{N} \mathrm{L}^{-1}$.

A previous study (McGroddy et al., 2008) investigated the types of nitrogen found in stream water from forests carefully selected as having no evidence of human disturbance within recent decades. Sites were excluded if estimates of $\mathrm{N}$ deposition indicated substantial inputs from adjacent animal agriculture $\left(>2 \mathrm{~kg} \mathrm{ha}^{-1} \mathrm{yr}^{-1}\right)$. The nitrogen content of stream water was found to be dominated by organic forms, with DON contributing substantially more (81.3\%) than nitrate-N (12.6\%) or ammonium-N (3.9\%) forms (McGroddy et al., 2008). While organic- $\mathrm{N}$ forms dominated in most streams, inorganic forms dominated in 18 out of the 97 watersheds tested. Results from other New Zealand studies (Neary et al., 1978; Duggan et al., 2002) (of sites without volcanic or animal $\mathrm{N}$ inputs) have followed a similar pattern, though dominance of DON was less marked. This pattern of $\mathrm{N}$ loss is consistent with that found in undisturbed temperate forests in southern South America (estimated atmospheric deposition $<1 \quad \mathrm{~kg} \mathrm{~N} \mathrm{ha}^{-1} \mathrm{yr}^{-1}$ ) indicating that dominance of organic over inorganic forms is characteristic of undisturbed temperate forests (Hedin et al. 1995; Perakis and Hedin 2002). Nitrogen concentrations in New Zealand streams were similar to those found in Chile and Argentina (McGroddy et al. 2008) with values approximately 10-fold lower than those of minimally disturbed forests at 17 states across the United States with higher atmospheric N deposition than New Zealand (< $10 \mathrm{~kg} \mathrm{ha}^{-1} \mathrm{yr}^{-1}$, Lewis 2002) and Finland ( $<6 \mathrm{~kg} \mathrm{ha}^{-1} \mathrm{yr}^{-1}$, Kortelainen et al. 2006), though similar to undisturbed forest in Oregon, USA where N deposition was $<2 \mathrm{~kg} \mathrm{ha}^{-1} \mathrm{yr}^{-1}$ (Vanderbilt et al. 2002).

Total $\mathrm{N}$ leaching loss from indigenous forest mostly ranges between 0.25 and $2.5 \mathrm{~kg} \mathrm{ha}^{-1} \mathrm{yr}^{-1}$ (Additional file 1: Table S1), however up to $5 \mathrm{~kg} \mathrm{ha}^{-1} \mathrm{yr}^{-1}$ may be lost from forests with high volcanic $\mathrm{N}$ inputs (Parfitt et al. 2002, 2003b). McGroddy et al. (2008) used a simple water-balance model and a regression approach to predict DON leaching loss from undisturbed forests with low atmospheric $\mathrm{N}$ inputs. Their estimates indicated losses of $<0.2-2.5 \mathrm{~kg} \mathrm{ha}^{-1} \mathrm{yr}^{-1}$ for most of the country, but losses of up to $12 \mathrm{~kg} \mathrm{ha}^{-1} \mathrm{yr}^{-1}$ could occur in small areas to the west of the South Island main divide with very high hydrologic throughput. Because of the predominance of organic- $\mathrm{N}$ in their samples, total $\mathrm{N}$ losses should not greatly exceed these estimates.

\section{Impacts of harvesting}

Studies on the effects of harvesting on the chemistry of streams draining indigenous forest catchments have been undertaken in beech/podocarp/hardwood forest at Big Bush in Nelson and at Maimai on the West Coast. At Big Bush, harvesting increased total $\mathrm{N}$ leaching loss 10-fold. Leaching loss remained 3-5 times higher in logged than control (unlogged) catchments four years after logging and had not returned to control levels by six years after harvest (Fahey and Jackson 1997). Harvesting increased concentrations of nitrate- $\mathrm{N}$ and organic-N, but not ammonium-N. Despite the increase in total $\mathrm{N}$, stream concentrations seldom exceeded $1 \mathrm{mg} \mathrm{N} \mathrm{L}{ }^{-1}$. At Maimai, a combination of logging and slash burning increased nitrate- $\mathrm{N}$ leaching loss by up to four-fold in the first year, and up to 20-fold in the second year (O'Loughlin et al. 1980). Specifically, nitrate-N leaching losses were increased from about $0.5 \mathrm{~kg} \mathrm{ha}^{-1} \mathrm{yr}^{-1}$ in control catchments to up to $10.4 \mathrm{~kg} \mathrm{ha}^{-1} \mathrm{yr}^{-1}$ in a catchment that had been harvested followed by slash burning. Longer-term data from catchments that had been harvested with slash either burnt or not burnt indicated smaller losses of $\mathrm{N}$, of the order of 1.2-2.7 $\mathrm{kg} \mathrm{ha}^{-1} \mathrm{yr}^{-1}$ (compared to control catchment losses of $0.5 \mathrm{~kg} \mathrm{ha}^{-1} \mathrm{yr}^{-1}$ ), over an 8-year period (Rowe and Fahey 1991). Ammonium-N concentrations were increased as a result of slash-burning following logging, but the increase was short lived, with concentrations returning to pre-treatment levels within about two months of treatment (Mosley and Rowe 1981). 


\section{Nitrogen in soil water}

The only information currently available on soil water $\mathrm{N}$ concentrations in indigenous forests is for five beech forests in the Canterbury and West Coast regions of the South Island (Davis 1990; data not shown). Concentrations of nitrate- $\mathrm{N}$ in soil water extracted by centrifugation from samples collected at 0.3-0.4 $\mathrm{m}$ depth ranged

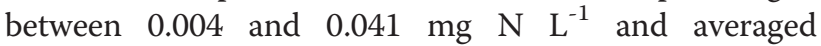
$0.018 \mathrm{mg} \mathrm{N} \mathrm{L}^{-1}$. These concentrations are within the range of those found in streams draining indigenous forest (Additional file 1: Table S1) although ion concentrations in centrifuged samples may be higher than in lysimeter samples (e.g. Zabowski 1989).

\section{Nitrogen leaching from planted forests Nitrogen losses in stream water}

Forests planted on non-agricultural land Few studies have examined $\mathrm{N}$ concentrations in streams draining forests planted on non-agricultural land (land that has not been cultivated, fertilised or seeded with pasture species). The measurements available indicate that $\mathrm{N}$ concentrations and total- $\mathrm{N}$ leaching losses are mostly similar to those from indigenous forests (Additional file 1: Table S2). Stenzel and Herrmann (1990) found the mean nitrate- $\mathrm{N}$ concentration on a single day was $0.021 \mathrm{mg} \mathrm{N} \mathrm{L}^{-1}$ from seven South Island streams draining planted forests that had not been affected by animal agriculture. The same authors obtained a similar value $\left(0.018 \mathrm{mg} \mathrm{N} \mathrm{L}^{-1}\right)$ for streams draining indigenous forests that had also been unaffected by animal agriculture, Additional file 1: Table S1. A national survey of lowland rivers where planted forests were the dominant, but not necessarily the only land use, found mean oxidised-N (nitrate + nitrite) and ammonium-N concentrations of 0.15 and $0.07 \mathrm{mg} \mathrm{N} \mathrm{L}^{-1}$ respectively (Larned et al. 2004). These values were significantly lower than pastoral classes of land but not significantly different from values for indigenous forests examined in the same study. A stream draining planted forest in the Rangitaiki catchment, Bay of Plenty region, is an exception to the generally low $\mathrm{N}$ concentrations found in forests planted on nonagricultural land. In this stream, nitrate- $\mathrm{N}$ concentrations ranged between 1 and $2.5 \mathrm{mg} \mathrm{N} \mathrm{L}^{-1}$ (Collier and Bowman 2003). Atmospheric inputs from volcanic activity may have contributed to the higher than normal nitrate concentrations in this stream (e.g. Parfitt et al. 2002).

Forests planted on pasture land Since the 1960s, many forests have been established on pasture land during periods when economic returns from livestock farming have been poor (Beets et al. 2001). It has been standard practice for New Zealand farmers to apply phosphate fertiliser to stimulate pasture legume growth in order to increase N-fixation and thus to improve pasture productivity. Consequently, forests of radiata pine planted on pasture are likely to have had higher labile soil $\mathrm{N}$ levels than indigenous forests or radiata pine forests established on non-agricultural land. While $\mathrm{N}$ concentrations in streams draining planted forests grown on pasture land are higher than in streams from indigenous forests and from planted forests planted on non-agricultural land (Additional file 1: Table S2), most of the values for planted forests on pasture land were from a single site (the Purukohukohu Experimental Basin in the central North Island), and were consequently influenced by high volcanic $\mathrm{N}$ inputs. Further studies are required to confirm that N-leaching from ex-pasture forests is greater than from forests planted on non-agricultural land.

Nitrogen concentrations and total $\mathrm{N}$ leaching losses in the Puruki catchment of the Purukohkohu Experimental Basin have been measured since the forest was established and have varied greatly over the life of the forest (Additional file 1: Table S2). No $\mathrm{N}$ fertiliser was applied at forest establishment (Beets and Brownlie 1987) or subsequently (P. Beets pers comm). Part of the variation is due to sampling location; some samples were from the base of the stream draining the catchment while others were from springs. Additionally, the data of Parfitt et al. (2002) are for a sub-catchment (Rua) of the Puruki catchment, rather than the whole catchment. Quinn and Ritter (2003) obtained Puruki-catchment nitrate-N concentrations and leaching losses over an extended period from samples collected monthly at a stream weir (Figure 1). Concentration and leaching loss data for samples taken at the stream weir have also been presented by Cooper et al. (1987), Cooper and Thomsen (1988) and Dyck et al. (1987) (Additional file 1: Table S2). The nitrate- $\mathrm{N}$ leaching loss from the pasture prior to planting was $5.7 \mathrm{~kg} \mathrm{~N} \mathrm{ha}^{-1} \mathrm{yr}^{-1}$ (Figure 1b). The loss increased to $11.1 \mathrm{~kg} \mathrm{~N} \mathrm{ha}^{-1} \mathrm{yr}^{-1}$ in the year following planting before declining to pre-planting levels in year two. The leaching loss then declined to $1-2 \mathrm{~kg} \mathrm{~N} \mathrm{ha}^{-1} \mathrm{yr}^{-1}$ between years three and five and to less than $1 \mathrm{~kg} \mathrm{~N} \mathrm{ha}^{-1} \mathrm{yr}^{-1}$ between years 6 and 14 (Figure 1b). Records were not collected between years 15 and 23. Nitrate- $\mathrm{N}$ leaching losses were higher from the mature pine forest, just before logging, than in the young forest phase (years 3-14). Although there are gaps in the monitoring record, these results suggest that nitrate retention by the pine forest is greatest when the pine crop has established and is growing vigorously, but the forest becomes more prone to nitrate loss by leaching as it matures (Quinn and Ritter 2003). Nitrate- $\mathrm{N}$ losses in the year of logging and the first year after logging increased to 3.9 and $4.5 \mathrm{~kg} \mathrm{~N} \mathrm{ha}^{-1} \mathrm{yr}^{-1}$ respectively, but decreased rapidly towards levels seen during the young forest phase. Parfitt et al. (2002) showed that this reduction was associated with weed 

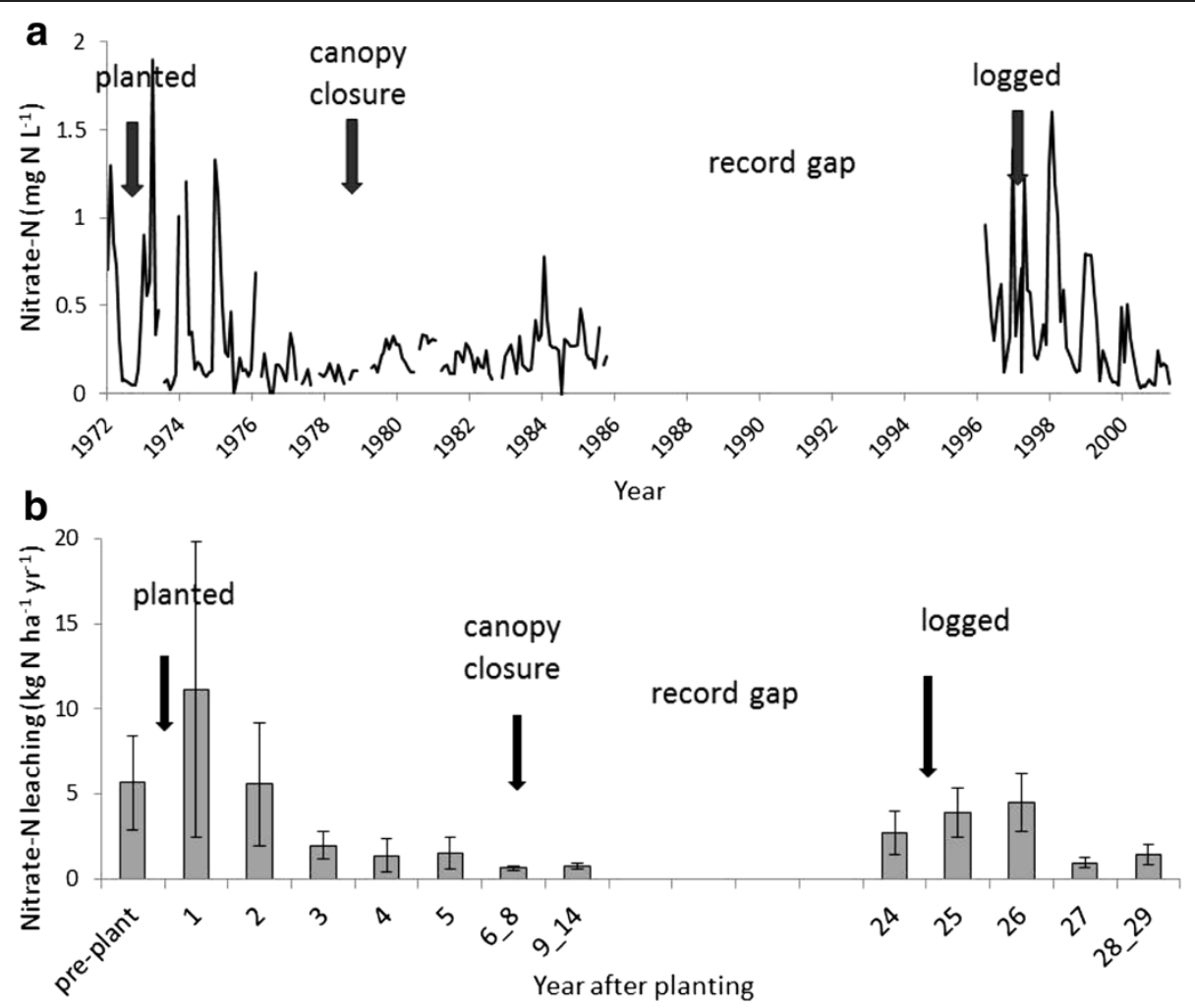

Figure 1 Long-term variation in nitrate concentrations (a) and leaching losses (b) in stream flow from Puruki catchment of pasture before radiata pine planting, through tree planting, growth and logging to regrowth of the second rotation crop. Data was obtained monthly. Bars show standard errors. After Quinn and Ritter (2003).

growth and an increase in microbial biomass after harvest which would have removed much of the $\mathrm{N}$ in the soil solution in the upper soil layers. Spring water nitrate-N concentrations and leaching losses in Rua subcatchment (Parfitt et al. 2002) were substantially higher than those in stream water (Additional file 1: Table S2), because of denitrification in the riparian zone and/or in-stream plant uptake of $\mathrm{N}$ (Cooper et al. 1987, Cooper and Thomsen 1988).

\section{Nitrogen in soil water}

Forests planted on non-agricultural land Soil-water nitrate- $\mathrm{N}$ concentrations ranged between 0 and $4 \mathrm{mg} \mathrm{N} \mathrm{L}^{-1}$ in forests planted on non-agricultural land, (Additional file 1: Table S3). Highest concentrations were found at Woodhill forest (Auckland), in samples collected in the first year after harvesting of a 32-year old stand of radiata pine. However, nitrate- $\mathrm{N}$ concentrations at this site rapidly fell to low levels in the following two years (Smith et al. 1994). Elsewhere, concentrations exceeded $0.3 \mathrm{mg} \mathrm{N} \mathrm{L}^{-1}$ at four sites, three of which were known to have a history of Ulex europaeus L. (gorse) infestation (Davis et al. 2012). Gorse, which fixes nitrogen, is likely to have contributed to the higher concentrations of soil-water nitrate-N at those sites (Dyck et al. 1983,
Magesan et al. 2012). The remaining site was beneath a slash windrow at Santoft Forest where concentrations were more than ten-fold greater than in samples from between windrows (Parfitt et al. 1997a). Nitrate-N concentrations at other sites were mostly less than $0.1 \mathrm{mg} \mathrm{N} \mathrm{L}^{-1}$. These values were similar to those found for streams draining indigenous forest or forest planted on non-agricultural land. Ammonium-N concentrations ranged between 0.01 and $0.49 \mathrm{mg} \mathrm{N} \mathrm{L}^{-1}$, and were generally higher at the sites where gorse had been present than at other sites. Ammonium-N concentrations were notably high at a site near Bulls, Manawatu. Soil at this site is coastal sand that has a low cation-exchange capacity and therefore little ability to retain ammonium ions. Soil water generally contained higher concentrations of dissolved organic- $\mathrm{N}$ than mineral-N. Also, soil water concentrations of dissolved organic- $\mathrm{N}$ exceeded stream water concentrations from either indigenous or planted forests.

Knight and Will (1977) found that no N leached from below the root zone (lysimeter depth of $2.7 \mathrm{~m}$ ) of 5-12year old radiata pine trees at Kaingaroa Forest, although DON was not measured. The highest level of $\mathrm{N}$ leaching recorded in soil-water samples from the lower zoot zone to date is $7.1 \mathrm{~kg} \mathrm{ha}^{-1} \mathrm{yr}^{-1}$, found at two sites (Tarawera, 
Bay of Plenty and Bulls, Manawatu; (Davis et al. 2012)). Average total- $\mathrm{N}$ leaching estimated from lower root zone soil water samples from planted forests on nonagricultural land, calculated using the data in Additional

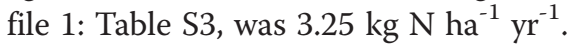

Forests planted on pasture land The Purukokohu Basin provides most of the data available for lower root zone leaching from planted forest established on pasture land (Additional file 1: Table S4). In the Puruki-Rua subcatchment, lower root zone soil water nitrate concentrations ranged between 0.28 and $3.5 \mathrm{mg} \mathrm{N} \mathrm{L}^{-1}$, and total $\mathrm{N}$ leaching losses ranged between less than 1 and $28 \mathrm{~kg} \mathrm{~N} \mathrm{ha}^{-1} \mathrm{yr}^{-1}$ (Dyck et al. 1987, Parfitt et al. 2002). In a stand thinned from 2000 to 550 stems ha $^{-1}$, total lower root zone $\mathrm{N}$ leaching increased from mid-rotation (4.9 $\mathrm{kg} \mathrm{N} \mathrm{ha}^{-1} \mathrm{yr}^{-1}$ ) to peak in the year of harvest $\left(28 \mathrm{~kg} \mathrm{~N} \mathrm{ha}^{-1} \mathrm{yr}^{-1}\right)$, then declined rapidly to low levels (less than $1 \mathrm{~kg} \mathrm{~N} \mathrm{ha}^{-1} \mathrm{yr}^{-1}$ ) within two years of replanting, following the pattern described by Quinn and Ritter (2003) for stream water draining the whole Puruki catchment (see above). A similar temporal pattern is also evident at an ex-farm site at Massey, Manawatu where total mineral $\mathrm{N}$ leaching losses declined rapidly from $18 \mathrm{~kg} \mathrm{~N} \mathrm{ha}^{-1} \mathrm{yr}^{-1}$ in the year of conversion of pasture to young forest, to less than $1 \mathrm{~kg} \mathrm{~N} \mathrm{ha}^{-1} \mathrm{yr}^{-1}$ in the second year. By year 9 , after canopy closure and $\mathrm{N}$ demand by the tree crop had declined, leaching had increased to $4.5 \mathrm{~kg} \mathrm{ha}^{-1} \mathrm{yr}^{-1}$ (Parfitt and Ross 2011). A similar transition occurred at age ten in the second rotation of a site at Tikitere, Bay of Plenty, where nitrate- $\mathrm{N}$ leaching increased from $0.2 \mathrm{~kg} \mathrm{~N} \mathrm{ha}^{-1}$ in the first 11 months of the sampling period to $28.7 \mathrm{~kg} \mathrm{~N} \mathrm{ha}^{-1}$ in the following 18 months (Davis et al., 2012).

\section{Effects of management practices on $\mathrm{N}$ leaching in planted forests \\ Impact of $\mathrm{N}$ fertilisation on stream water}

Only two studies in New Zealand have examined the impact of the aerial application of fertiliser to forests on stream water (Leonard 1977; Neary and Leonard 1978). Both indicate that effects are likely to be minimal, consistent with studies reviewed by Binkley et al. (1999) for regions not saturated by atmospheric $\mathrm{N}$ deposition. Leonard (1977) studied the impact of fertilisation on stream water draining Pumice soils in Kaingaroa Forest. Nitrogen was applied at $230 \mathrm{~kg} \mathrm{~N} \mathrm{ha}^{-1}$ as urea to 126 hectares of immature radiata pine stands at varying stages of canopy closure (Table 1). No attempt was made to avoid the stream channel. The fertiliser was applied to the lower part of the catchment; the upstream part provided an unfertilised control. The total- $\mathrm{N}$ from fertiliser that ended up in stream water was $95 \mathrm{~kg}\left(<1 \mathrm{~kg} \mathrm{~N} \mathrm{ha}^{-1}\right)$, equivalent to $0.33 \%$ of the $\mathrm{N}$ applied (Table 1). Half of this occurred during the first week by direct fall into the stream. The initial inputs to stream water were mainly in organic form (as urea) or as ammonia-N. This is typical of fertilisation with urea, particularly if streams are not avoided during fertiliser application (Binkley et al. 1999). The remaining inputs to stream water were associated with storm events occurring over the next four months. The peak nitrate- $\mathrm{N}$ concentration recorded in stream water $\left(1.2 \mathrm{mg} \mathrm{N} \mathrm{L}^{-1}\right)$ occurred following a rain event 6 weeks after fertilisation, while other peaks did not exceed $0.4 \mathrm{mg} \mathrm{N} \mathrm{L}^{-1}$. Leonard (1977) suggested that avoidance of a strip $20 \mathrm{~m}$ wide on either side of the stream would considerably reduce $\mathrm{N}$ losses to stream water.

Neary and Leonard (1978) subsequently monitored total- $\mathrm{N}$ concentrations in two streams after urea fertilisation $\left(92 \mathrm{~kg} \mathrm{~N} \mathrm{ha}^{-1}\right)$ of forest on central yellow brown earth soils developed on Moutere gravels in the Nelson province. Fertiliser was applied aerially over one stream channel but not the other. Small increases $\left(<1 \mathrm{mg} \mathrm{N} \mathrm{L}^{-1}\right)$ in total-N concentrations were observed in both streams. Overall losses from the two catchments could not be accurately assessed because of lack of stream flow data but the authors estimated that total- $\mathrm{N}$ losses to stream water amounted to $<0.1 \%$ of that applied.

\section{Impact of $\mathrm{N}$ fertilisation on soil water}

Increased $\mathrm{N}$ concentrations in the lower root zone of forest trees following application of fertiliser indicate a potential for increased stream water concentrations. Studies of the effect of fertiliser application on root-zone soil drainage water $\mathrm{N}$ concentrations in New Zealand forests have found average increases ranging from 0 to $35 \mathrm{mg} \mathrm{N} \mathrm{L}{ }^{-1}$ of nitrate-N (Table 1). In a benchmark study, Worsnop and Will (1980) investigated N leaching after fertiliser application to recently thinned 13-year-old radiata pine growing on pumice soil in Kaingaroa Forest with $200 \mathrm{~kg} \mathrm{~N} \mathrm{ha}^{-1}$. No leaching of $\mathrm{N}$ (of any form) was found to $2.7 \mathrm{~m}$ depth during the three year monitoring period after fertiliser application. Fertilisation had no significant impact on $\mathrm{N}$ leaching below 0.6-1.0 m depth at six of ten sites studied by Davis et al. (2012) where $\mathrm{N}$ was also applied at $200 \mathrm{~kg} \mathrm{~N}^{-1}$ (Table 1), However, lower root zone $\mathrm{N}$ concentrations were significantly affected at the remaining four sites. The largest increase in mean nitrate- $\mathrm{N}$ concentration $\left(\sim 35 \mathrm{mg} \mathrm{N} \mathrm{L}^{-1}\right)$ occurred on a coastal sand in the Manawatu region. Fertilisation also caused substantial, though lower increases on a coastal sand in the Auckland region and on a pallic soil in Canterbury (Table 1). These three sites all had recent infestations of a $\mathrm{N}$-fixing shrub (Ulex europeus or Lupinus arboreus sims) (Smith et al. 1994, Davis et al. 2012). In the study of Davis et al. (2012), factors that seemed to predispose sites to nitrate- $\mathrm{N}$ leaching following fertiliser 
Table 1 Nitrate-N response in stream water and lower root zone soil drainage water to fertilisation with urea

\begin{tabular}{|c|c|c|c|c|c|c|c|c|c|c|c|}
\hline \multicolumn{3}{|c|}{ Site details } & \multirow{2}{*}{$\begin{array}{l}\text { Fertiliser } \\
\text { application } \\
\text { rate } \\
\left(\mathrm{kg} \mathrm{N} \mathrm{ha}^{-1}\right)\end{array}$} & \multicolumn{5}{|c|}{ Nitrate-N response } & \multirow{2}{*}{$\begin{array}{l}\text { Time after } \\
\text { application } \\
\text { for maximum } \\
\text { effect (weeks) }\end{array}$} & \multirow{2}{*}{$\begin{array}{l}\text { Lysimeter } \\
\text { depth }(m)\end{array}$} & \multirow{2}{*}{ Reference } \\
\hline Location & Soil Group & $\begin{array}{l}\text { Stand age } \\
\text { at fertilisation } \\
\text { (years) }\end{array}$ & & $\begin{array}{l}\text { Mean nitrate } \\
\text { concentration } \\
\text { prior to fertiliser } \\
\text { application }\left(\mathrm{mg} \mathrm{L}^{-1}\right)^{1}\end{array}$ & $\begin{array}{l}\text { Mean nitrate } \\
\text { concentration } \\
\text { after fertiliser } \\
\text { application } \\
\left(\mathrm{mg} \mathrm{L}^{-1}\right)\end{array}$ & $\begin{array}{l}\text { Increase in } \\
\text { mean nitrate } \\
\text { concentration } \\
\text { due to fertiliser } \\
\left(\mathrm{mg} \mathrm{L}^{-1}\right)\end{array}$ & $\begin{array}{l}\text { Maximum nitrate } \\
\text { concentration after } \\
\text { fertiliser application } \\
\left(\mathrm{mg} \mathrm{L}^{-1}\right)^{1}\end{array}$ & $\begin{array}{l}\text { Fertiliser } N \\
\text { lost to stream } \\
\text { or drainage water } \\
\left(\mathrm{kg} \mathrm{ha}^{-1}\right)^{1}\end{array}$ & & & \\
\hline \multicolumn{12}{|c|}{ Stream water } \\
\hline $\begin{array}{l}\text { Kinleith } \\
\text { Central NI }\end{array}$ & Pumice & Immature & 230 & $<\mathrm{dl}^{2}$ & - & & 1.2 & $<1(0.33 \%)$ & 6 & & $\begin{array}{l}\text { Leonard } \\
\text { (1977) }\end{array}$ \\
\hline $\begin{array}{l}\text { Motueka } \\
\text { Nelson }\end{array}$ & Brown & Not known & 92 & $0.32-0.56$ & - & & 0.72 & $(<0.1 \%)$ & 2 & & $\begin{array}{l}\text { Neary and } \\
\text { Leonard } \\
\text { (1978) }\end{array}$ \\
\hline $\begin{array}{l}\text { Motueka } \\
\text { Nelson }\end{array}$ & Brown & Not known & 92 & $0.19-0.26$ & - & & 0.79 & $(<0.1 \%)$ & 7 & & $\begin{array}{l}\text { Neary and } \\
\text { Leonard } \\
\text { (1978) }\end{array}$ \\
\hline \multicolumn{12}{|c|}{ Lower root zone soil drainage water } \\
\hline $\begin{array}{l}\text { Kaingaroa } \\
\text { Central NI }\end{array}$ & Pumice & 13 & 200 & $<\mathrm{dl}$ & $<\mathrm{dl}$ & 0 & $<\mathrm{dl}$ & $0(0 \%)$ & - & 2.7 & $\begin{array}{l}\text { Worsnop } \\
\text { and Will } \\
\text { (1980) }\end{array}$ \\
\hline $\begin{array}{l}\text { Bottle Lake } \\
\text { Canterbury }\end{array}$ & $\begin{array}{l}\text { Recent } \\
\text { Coastal } \\
\text { sand }\end{array}$ & 2 & 150 & $0-2.5$ & - & - & 24 & $54(36 \%)$ & - & & $\begin{array}{l}\text { Thomas } \\
\text { and Mead } \\
\text { (1992) }\end{array}$ \\
\hline $\begin{array}{l}\text { Woodhill } \\
\text { Auckland }\end{array}$ & $\begin{array}{l}\text { Recent } \\
\text { Coastal } \\
\text { sand }\end{array}$ & $0^{3}$ & $450^{7}$ & $1.4^{8}$ & $\begin{array}{l}8 \\
8\end{array}$ & 6.6 & $18^{8}$ & $26^{9}(6 \%)$ & 38 & 0.6 & $\begin{array}{l}\text { Smith } \\
\text { et al. } \\
\text { (1994) }\end{array}$ \\
\hline $\begin{array}{l}\text { Woodhill } \\
\text { Auckland }\end{array}$ & $\begin{array}{l}\text { Recent } \\
\text { Coastal } \\
\text { sand }\end{array}$ & $0^{4}$ & $450^{7}$ & $2.9^{8}$ & $12^{8}$ & 9.1 & $25^{8}$ & $36^{9}(8 \%)$ & 98 & 0.6 & $\begin{array}{l}\text { Smith } \\
\text { et al. } \\
\text { (1994) }\end{array}$ \\
\hline $\begin{array}{l}\text { Woodhill } \\
\text { Auckland }\end{array}$ & $\begin{array}{l}\text { Recent } \\
\text { Coastal } \\
\text { sand }\end{array}$ & $0^{5}$ & $450^{7}$ & $1.1^{8}$ & $8^{8}$ & 6.9 & $24^{8}$ & $28^{9}(6 \%)$ & 30 & 0.6 & $\begin{array}{l}\text { Smith } \\
\text { et al. } \\
\text { (1994) }\end{array}$ \\
\hline $\begin{array}{l}\text { Woodhill } \\
\text { Auckland }\end{array}$ & $\begin{array}{l}\text { Recent } \\
\text { Coastal } \\
\text { sand }\end{array}$ & $0^{6}$ & $450^{7}$ & $0.8^{8}$ & $12^{8}$ & 11.2 & $46^{8}$ & $45^{9}(10 \%)$ & 120 & 0.6 & $\begin{array}{l}\text { Smith } \\
\text { et al. } \\
\text { (1994) }\end{array}$ \\
\hline $\begin{array}{l}\text { Tikitere } \\
\text { Bay of } \\
\text { Plenty }\end{array}$ & Pumice & 9 & 200 & 3.14 & 3.34 & 0.2 & 6.15 & 11.5 (5.7\%) & 56 & 1.0 & $\begin{array}{l}\text { Davis et al. } \\
\text { (2012) }\end{array}$ \\
\hline $\begin{array}{l}\text { Mamaku } \\
\text { Bay of } \\
\text { Plenty }\end{array}$ & Podzol & 7 & 200 & 0.08 & 2.79 & 2.71 & 3.83 & $28.4(14.2 \%)$ & 48 & 1.0 & $\begin{array}{l}\text { Davis et al. } \\
\text { (2012) }\end{array}$ \\
\hline
\end{tabular}


Table 1 Nitrate-N response in stream water and lower root zone soil drainage water to fertilisation with urea (Continued)

\begin{tabular}{|c|c|c|c|c|c|c|c|c|c|c|c|}
\hline $\begin{array}{l}\text { Tarawera } \\
\text { Bay of } \\
\text { Plenty }\end{array}$ & Recent & 9 & 200 & 0.06 & 0.25 & 0.19 & 0.53 & 1.7 (0.8\%) & - & 1.0 & $\begin{array}{l}\text { Davis et al. } \\
\text { (2012) }\end{array}$ \\
\hline $\begin{array}{l}\text { Waimarino } \\
\text { Wanganui }\end{array}$ & Allophanic & 8 & 200 & 0.03 & 1.44 & 1.41 & 2.54 & $12.1(6.0 \%)$ & 37 & 0.9 & $\begin{array}{l}\text { Davis et al. } \\
\text { (2012) }\end{array}$ \\
\hline $\begin{array}{l}\text { Karioi } \\
\text { Wanganui }\end{array}$ & Allophanic & 8 & 200 & 0.04 & 0.03 & -0.01 & 0.05 & $0(0 \%)$ & - & 1.0 & $\begin{array}{l}\text { Davis et al. } \\
\text { (2012) }\end{array}$ \\
\hline $\begin{array}{l}\text { Bulls } \\
\text { Manawatu }\end{array}$ & $\begin{array}{l}\text { Brown } \\
\text { Coastal } \\
\text { sand }\end{array}$ & 8 & 200 & 2.00 & 37.31 & 35.31 & 81.0 & 90.8 (45.4\%) & 29 & 1.0 & $\begin{array}{l}\text { Davis et al. } \\
\text { (2012) }\end{array}$ \\
\hline $\begin{array}{l}\text { Ashley } \\
\text { Canterbury }\end{array}$ & Pallic & 9 & 200 & 0.32 & 11.20 & 10.88 & 39.3 & $15.2(7.6 \%)$ & 10 & 0.8 & $\begin{array}{l}\text { Davis et al. } \\
\text { (2012) }\end{array}$ \\
\hline $\begin{array}{l}\text { Eyrewell } \\
\text { Canterbury }\end{array}$ & Brown & 7 & 200 & 3.19 & 2.70 & -0.49 & 2.70 & $0.2(0.1 \%)$ & 17 & 0.6 & $\begin{array}{l}\text { Davis et al. } \\
\text { (2012) }\end{array}$ \\
\hline $\begin{array}{l}\text { Otago } \\
\text { Coast }\end{array}$ & Brown & 8 & 200 & 0.05 & 0.14 & 0.09 & 0.43 & $0.2(0.2 \%)$ & - & 1.0 & $\begin{array}{l}\text { Davis et al. } \\
\text { (2012) }\end{array}$ \\
\hline $\begin{array}{l}\text { Catlins } \\
\text { Otago }\end{array}$ & Brown & 8 & 200 & 0.18 & 3.73 & 3.55 & 6.47 & $10.3(5.1 \%)$ & 21 & 1.0 & $\begin{array}{l}\text { Davis et al. } \\
\text { (2012) }\end{array}$ \\
\hline $\begin{array}{l}1{ }^{1} \text { Total fertilise } \\
2 \text { Less than d } \\
3 \text { stem only h } \\
4 \text { stem only h } \\
5 \text { whole tree } \\
6 \text { whole tree } \\
750 \mathrm{~kg} \mathrm{~h}^{-1} \text {, } \\
{ }^{8} \text { values estim } \\
{ }^{9} \text { values estim }\end{array}$ & $\begin{array}{l}\text { er } N \text { lost as a p } \\
\text { letection limit. } \\
\text { harvest. } \\
\text { harvest, double } \\
\text { harvest. } \\
\text { harvest and fo } \\
\text { 3-monthly for } \\
\text { hated from gra } \\
\text { hated assuming }\end{array}$ & & & & & & & & & & \\
\hline
\end{tabular}


application were a recent pasture history, the presence of a high component of Ulex europeus in the understorey, and/or a low soil $\mathrm{C} / \mathrm{N}$ ratio.

Maximum nitrate- $\mathrm{N}$ concentrations in soil water after fertilisation greatly exceeded those in stream water (Table 1). Denitrification in the riparian zone, in-stream removal and mixing with other water may have all contributed to the smaller amounts detected in stream water (see reviews by Binkley et al. 1999, Gundersen et al. 2006). Although high peak values were recorded, elevated nitrate- $\mathrm{N}$ concentrations in soil drainage water after fertiliser application were generally short lived; average concentrations after fertiliser application exceeded $10 \mathrm{mg} \mathrm{N} \mathrm{L}^{-1}$ for at least a year only in the study of Smith et al. (1994) where fertiliser was applied quarterly to a coastal-sand site at $50 \mathrm{~kg} \mathrm{~N} \mathrm{ha}^{-1}$ for 2.5 years. Average nitrate- $\mathrm{N}$ concentrations exceeded $10 \mathrm{mg} \mathrm{N} \mathrm{L}^{-1}$ at two sites in the study of Davis et al. (2012), but only for short periods. In contrast, Binkley et al. (1999) found that in a substantial portion of studies they reviewed, average nitrate- $\mathrm{N}$ concentrations remained at more than $10 \mathrm{mg} \mathrm{N} \mathrm{L}^{-1}$ for at least a year after fertilisation, possibly reflecting that these sites had reached $\mathrm{N}$ saturation from atmospheric $\mathrm{N}$ deposition.

In soil-water drainage studies, losses measured in the lower root zone have ranged from $0-91 \mathrm{~kg} \mathrm{~N} \mathrm{ha}^{-1}(0-$ $45 \%$ of $\mathrm{N}$ applied) (Table 1). The highest losses were recorded on coastal sands in the Manawatu region $\left(91 \mathrm{~kg} \mathrm{~N} \mathrm{ha}^{-1}\right.$ ) and Canterbury (54 kg N ha ${ }^{-1}$ ) (45 and $36 \%$ of $\mathrm{N}$ applied, respectively). Reduced losses (26$45 \mathrm{~kg} \mathrm{~N} \mathrm{ha}^{-1}, 6-10 \%$ of $\mathrm{N}$ applied) were recorded in the different harvesting treatments on coastal sand at Woodhill Forest, Auckland (Smith et al. 1994), possibly because $\mathrm{N}$ was applied on a number of occasions over a period of 2-3 years. However Smith et al. (1994) did not measure ammonium- $\mathrm{N}$ concentrations, and leaching losses may have been underestimated as ammonium- $\mathrm{N}$ leaching may occur following fertiliser application on sands (Thomas and Mead 1992). In an earlier study on coastal sand at Woodhill Forest (not shown in Table 1 because of the length of time between fertiliser application and measurement), Baker et al. (1986) found no difference in $\mathrm{N}$ leaching between fertilised (a total of $960 \mathrm{~kg} \mathrm{ha}^{-1} \mathrm{~N}$ over ten years) and unfertilised plots. The comparison was made 14 years after the initial $\mathrm{N}$ application and, although drainage losses at the time of measurement were low $\left(<0.2 \mathrm{~kg} \mathrm{~N} \mathrm{ha}^{-1} \mathrm{yr}^{-1}\right.$; Additional file 1 : Table S3), significant losses in the period since fertiliser was applied were indicated. For example, in fertilisertreated plots, $340 \mathrm{~kg} \mathrm{~N} \mathrm{ha}^{-1}$ of the $\mathrm{N}$ additions were unaccounted for in biomass (exclusive of roots) and soil $\mathrm{N}$ to a depth of $1 \mathrm{~m}$. A proportion of the unaccounted for $\mathrm{N}$ would have been contained in root biomass and some may have been lost through volatilisation of ammonia after fertiliser application, but most is likely to have been lost through leaching. Losses from the lower root zone at non-coastal sand sites listed in Table 1 amounted to $0-28 \mathrm{~N} \mathrm{~kg} \mathrm{ha}^{-1}$ (0-14\% of the $\mathrm{N}$ applied).

The amount of potentially leachable nitrate- $\mathrm{N}$ in soildrainage water arising from fertilisation that would eventually reach streams is not known. Although lysimeters were located below the majority of roots in the studies listed in Table 1, a proportion of tree roots would inevitably occur below the lysimeters at most sites and absorb N. Binkley et al. (1999) noted they knew of no studies that had examined water chemistry profiles of nutrient concentrations through the soil profile into stream water. However, Parfitt et al. (2002) found no difference in nitrate- $\mathrm{N}$ between soil $0.6 \mathrm{~m}$ deep (determined using lysimeters) and near-by spring water in mature radiata pine forest on Pumice soil. These results suggest that the lysimeter data may accurately simulate the amount of $\mathrm{N}$ entering streams. Further studies are required to determine possible $\mathrm{N}$ differences between the lower root zone and streams at different sites.

\section{Influence of harvesting and subsequent vegetation management}

Harvesting of forests may lead to increased leaching loss of $\mathrm{N}$, as $\mathrm{N}$ uptake is disrupted. However losses appear to be small and short lived, and do not always occur. Ammonium-N concentrations increased marginally in the first year after harvesting of a mature radiata pine stand in Kaingaroa Forest with low pre-harvest $\mathrm{N}$ leaching losses. In contrast, harvesting followed by slash burning in the same forest produced a large increase in surface leachate ammonium-N concentrations. However, very little ammonium- $\mathrm{N}$ leached below $1 \mathrm{~m}$ in any treatment (Dyck et al. 1981). Harvesting caused a rapid increase in nitrate- $\mathrm{N}$ concentrations, which persisted through to the end of the study (approximately 36 months after logging). Harvesting followed by slash burning caused a shorter lived response. The two treatments caused only a minor increase (ca $10 \mathrm{~kg} \mathrm{~N} \mathrm{ha}^{-1}$ ) in the amount of nitrate- $\mathrm{N}$ leached over the 3-year course of the study (Figure 2). The plots had been treated with herbicide to control weed growth 14 months after harvesting, which would have exacerbated leaching losses (Parfitt et al. 2003a). Parfitt et al. (2002) found harvesting reduced nitrate- $\mathrm{N}$ loss, measured using lysimeters, from $28 \mathrm{~kg} \mathrm{~N} \mathrm{ha}^{-1} \mathrm{yr}^{-1}$ prior to harvest to less than $1 \mathrm{~kg} \mathrm{~N} \mathrm{ha}^{-1} \mathrm{yr}^{-1}$ three years after harvest on a pumice soil of high natural $\mathrm{N}$ status at the Purukohukohu experimental basin site (Additional file 1: Table S3). The reduction was attributed to $\mathrm{N}$ uptake by weeds (especially grass) that colonised the site after harvest, as well as enhanced microbial activity and incorporation of $\mathrm{N}$ into microbial biomass. 


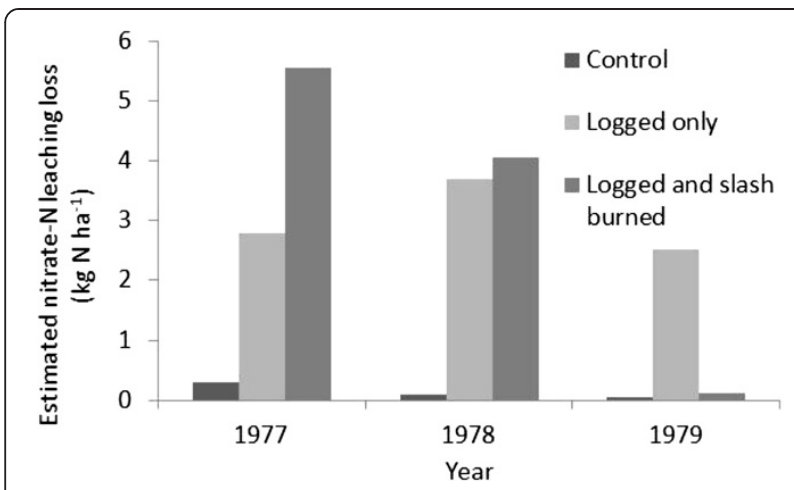

Figure 2 Impact of logging (1976) and burning (1977) operations on subsequently estimated nitrate- $\mathrm{N}$ leaching losses at $1 \mathrm{~m}$ depth in radiata pine forest on volcanic ash soil, Kaingaroa Forest. Leaching was estimated assuming drainage was one third of annual precipitation (1400 mm). After Dyck et al. (1981).

Leaching increases if weed growth after harvest is inhibited. Dyck et al. (1983) removed vegetation from trenched treeless plots (simulating harvesting) in Kaingaroa Forest. After 21 months, soil-water nitrate-N concentrations had risen to a maximum of $9.4 \mathrm{mg} \mathrm{N} \mathrm{L}^{-1}$ compared to $2.0 \mathrm{mg} \mathrm{N} \mathrm{L}^{-1}$ in an adjacent logged but unweeded area. Concentrations in unlogged controls were $0.002 \mathrm{mg} \mathrm{N} \mathrm{L}^{-1}$. Concentrations declined to $4 \mathrm{mg} \mathrm{N} \mathrm{L}^{-1}$ at the close of the study, 24 months after treatment. Competition removal by herbiciding spots (area around tree to which herbicide is applied for vegetation control) around trees at planting also causes increased leaching losses. Parfitt et al. (2003a) measured $\mathrm{N}$ leaching below $0.25 \mathrm{~m}$ under herbicided spots, rank pasture between trees, and nearby grazed pasture. The $\mathrm{N}$ leaching losses over a 14-month period amounted to $49 \mathrm{~kg} \mathrm{~N} \mathrm{ha}^{-1}$ under the trees, $15 \mathrm{~kg} \mathrm{~N}^{-1}$ under the rank grass and $3 \mathrm{~kg} \mathrm{~N} \mathrm{ha}{ }^{-1}$ under the pasture. The herbicided area under the trees was only $12 \%$ of the total land area, so the scaled contribution to leaching under the trees amounted to $5 \mathrm{~kg} \mathrm{~N}^{-1}$, compared to $13 \mathrm{~kg} \mathrm{~N}$ ha $^{-1}$ under pasture.

Smith et al. (1994) examined the impact of harvest intensity on root-zone nitrate leaching of a second rotation radiata pine forest on coastal sand dunes at Woodhill Forest in the Auckland region. The harvesting treatments were (1) whole-tree harvest and forest floor removal, (2) whole-tree harvest, (3) stem-only (conventional) harvest and (4) stem-only harvest with double the normal amount of slash returned. The plots were maintained in a weed-free condition throughout the trial. Where trees were conventionally harvested, nitrate- $\mathrm{N}$ concentrations at $0.6 \mathrm{~m}$ depth increased from about $0.5 \mathrm{mg} \mathrm{N} \mathrm{L}^{-1}$ to $4 \mathrm{mg} \mathrm{N} \mathrm{L}^{-1}$ at $30-40$ weeks after harvest before declining to negligible amounts by 80 weeks after harvest. Nitrate- $\mathrm{N}$ concentrations were substantially increased where double the amount of slash was added, but whole-tree harvesting and forest-floor removal appeared to have little overall effect on nitrate-N concentrations. Parfitt et al. (1997) also found substantially increased nitrate concentrations where slash was mounded in windrows (Additional file 1: Table S3).

\section{Reducing $\mathrm{N}$ leaching from planted forests}

While overall $\mathrm{N}$ leaching from planted forests is lower than from other major land uses, there are key times during the forest rotation when $\mathrm{N}$ leaching may occur, particularly in forest planted on fertile pasture land. Although losses are usually short-lived, it is advantageous to minimise $\mathrm{N}$ leaching at these key stages to limit adverse effects on the environment and maintain $\mathrm{N}$ in the soil for the benefit of crop nutrition.

\section{Loss in herbicide spots at tree establishment}

Herbicide use to reduce competition from weed species is often essential to achieve acceptable tree establishment (Rolando et al. 2011). Although $\mathrm{N}$ losses in individual spots may be relatively high, spots occupy a limited proportion of the total land area and so total losses per hectare are not large. Losses in spots may be minimised by keeping both the spot area and the duration when the ground is bare of vegetation to a minimum.

\section{Reducing $\mathrm{N}$ loss following fertiliser application}

Nitrate-N leaching losses are usually greatest during winter and early spring when drainage is occurring from the soil and plant uptake of $\mathrm{N}$ is low because of cooler conditions. Consequently, nitrate- $\mathrm{N}$ leaching losses are usually greatest during winter and early spring so leaching losses can be minimised by avoiding fertiliser application at these times. However, if low application rates are used then the timing of application may be less important. Thomas and Mead (1992) investigated measures to reduce leaching losses in coastal sands where $\mathrm{N}$ losses can be high. Aplication of $50 \mathrm{~kg} \mathrm{~N} \mathrm{ha}^{-1}$ to two-year-old radiata pine resulted in minimal $\mathrm{N}$ leaching losses, irrespective of whether the fertiliser was applied in autumn, spring or summer. Immobilisation of $\mathrm{N}$ in soil accounted for the majority of $\mathrm{N}$ not taken up by trees. When a higher rate of fertiliser $\left(150 \mathrm{~kg} \mathrm{~N} \mathrm{ha}^{-1}\right)$ was applied in a single application, up to $30 \%$ was lost by leaching below the main root zone $(0.3 \mathrm{~m})$ within the first two months, though little further loss occurred after that (up to 17 months). Splitting the fertiliser into three or nine individual applications resulted in more $\mathrm{N}$ being retained in the soil, and no leaching losses of fertiliser $\mathrm{N}$ below $0.8 \mathrm{~m}$ depth were observed. However splitting applications would incur more labour and machinery costs than if fertiliser was applied in a single application. 
Nitrification inhibitors can be used to reduce the rate at which ammonium ions are converted to nitrate ions in the soil after fertiliser application. They can also be used to reduce nitrate-N losses from urine patches. Such inhibitors have been used in pastoral farming in New Zealand to reduce $\mathrm{N}$ leaching losses (Cameron et al. 2013), but have not been considered for forest use. Nitrification inhibitors may, however, have a role in reducing leaching on N-rich forest sites between canopy closure and harvest when $\mathrm{N}$ demand by the crop falls and the forest begins to lose $\mathrm{N}$ by leaching (Quinn and Ritter 2003), particularly in catchments where forests may be planted to reduce $\mathrm{N}$ leaching to sensitive waterways. Nitrification inhibitors may not limit $\mathrm{N}$ losses on coastal-sand soils where forest leaching losses after fertilisation are greatest, as sands have low cation-exchange capacity and low organic matter content and, therefore, have limited capacity to retain either ammonium or nitrate ions. Nitrification inhibitors may also be of limited use at other forest sites found to be prone to $\mathrm{N}$ leaching following experimental fertiliser application (forests planted on fertile pasture land or with a high shrub legume content) as, in practice, fertilisation of such sites is unlikely to be economically feasible.

\section{Reducing $\mathbf{N}$ losses at harvest}

Nitrogen leaching losses at harvest may be most effectively reduced by rapid establishment of a vegetation cover after harvesting (Dyck et al. 1983, Parfitt et al. 2003). A cover of 'weeds' normally develops rapidly after harvest at most forest sites, however where this doesn't occur, grasses or other herbaceous species may be introduced by over-sowing (West et al. 1988, West 1995). Additionally, avoiding harvesting during winter and early spring would minimise leaching losses.

\section{Maximising tree $\mathrm{N}$ uptake}

Some factor(s) (e.g. disease, pests or deficiency of nutrients other than $\mathrm{N}$ ) may be the cause of limited forest growth that prevents maximum uptake of applied $\mathrm{N}$, resulting in increased $\mathrm{N}$ leaching. Correction of the limiting factor(s) may reduce potential $\mathrm{N}$ leaching.

\section{Selection of tree species to reduce $\mathbf{N}$ losses}

European studies have shown that, in areas of high atmospheric $\mathrm{N}$ deposition, nitrate ion concentrations in soil drainage water beneath Picea spp. (spruce) forests are about double those in drainage water beneath Fagus spp. (beech) forests (Rothe 2005). This occurs because Picea spp. forests have a higher leaf area than Fagus spp. forests. Also, being evergreen, the Picea spp. forests maintain the high leaf area throughout the year in contrast to deciduous Fagus spp. Higher leaf area leads to higher interception of atmospheric $\mathrm{N}$ and therefore higher $\mathrm{N}$ deposition rates. In areas of high atmospheric deposition, planting of deciduous forest species, or species with low leaf area, should reduce $\mathrm{N}$ deposition and $\mathrm{N}$ leaching. In areas where atmospheric deposition is low (as in most of New Zealand) however, leaching could increase under deciduous or low leaf area species because of reduced canopy interception of precipitation, and greater through fall and water movement through the soil. In areas with low $\mathrm{N}$ deposition at least, species with high growth rates and $\mathrm{N}$ uptake rates should reduce $\mathrm{N}$ leaching at a greater rate than species with low growth rates and $\mathrm{N}$ uptake rates. Rothe (2005) considered the effect of tree species on deposition rates was more important than other species-related processes that might affect $\mathrm{N}$ leaching losses. Nitrogen fixation may be an exception as $\mathrm{N}$-fixing species have been shown to increase nitrate levels in leaching water (Compton et al. 2003; Willard et al. 2005).

\section{Use of forests to reduce $\mathrm{N}$ leaching}

Conversion of fertile pasture land to planted forests rapidly reduces soil $\mathrm{N}$ leaching losses (Cooper and Thomsen 1988, Quinn and Ritter 2003, Parfitt et al. 2002) indicating forests have a potential role to play in reducing $\mathrm{N}$ leaching losses to rivers, lakes and groundwater. The measures noted above, particularly regarding use of nitrification inhibitors, choice of species with fast growth and $\mathrm{N}$ uptake rates and reducing losses at harvest by ensuring rapid site revegetation, could be used to maximise the 'planted forest effect'.

The greatest reduction in leaching occurs early in the life of the forest during canopy development. At some time after canopy closure, when there is less demand on soil $\mathrm{N}$ from the tree crop, $\mathrm{N}$ leaching increases. An example of this effect is shown in Figure 1. Use of fastgrowing short rotation crops (such as Eucalyptus nitens (Deane \& Maiden) for wood chip or pulp production) could be considered in areas where there is a strong need to reduce $\mathrm{N}$ leaching caused by intensive agriculture. Such species are harvested at a young age (1015 years), and then re-planted, ensuring continuing high demand on soil $\mathrm{N}$.

Conversion of pasture to forestry will lead to a reduction in nitrogen leaching. However, leaching will continue to be an on-going problem unless the soil nitrogen capital available to produce nitrate is significantly reduced. Nutrient-balance models, such as that developed for radiata pine (Smaill et al. 2011), may be useful in identifying the effect of management practices on soil $\mathrm{N}$ pools and optimising suitable strategies to reduce the excess nitrogen capital in the soil. Modelling should aid in determination of the optimal age of harvest and replanting to achieve maximum reduction soil $\mathrm{N}$. Modelling should also assist in evaluation of the effects of 
management practices, such as the removal of harvest residues and litter for off-site use, on soil nitrogen capital.

\section{Conclusions}

Nitrogen concentrations in streams draining indigenous forests in New Zealand are very low. Nitrogen concentrations in streams draining planted forests established on non-agricultural land are generally similar to those from indigenous forest, however limited stream water data are available for planted forests. Root-zone soilwater nitrate concentrations of planted forests established on non-agricultural land are higher where shrub legumes are present or for a short period after harvest.

Nitrogen concentrations in streams draining forests planted on pasture land are commonly higher than in streams from indigenous forests and from forests planted on non-agricultural land. However, most of the values for planted forests established on pasture land were influenced by high volcanic $\mathrm{N}$ inputs. Long-term data from one catchment study show that after fertile pasture is converted to pines, nitrate concentrations and leaching losses decline and remain low until at least mid-rotation, but the forest may become more prone to losing nitrate by leaching as it matures.

Only two studies have examined the effect of $\mathrm{N}$ fertiliser application to forests on stream water in New Zealand and both indicate that effects are likely to be minimal, consistent with international studies for regions not saturated by atmospheric $\mathrm{N}$ deposition. However fertilisation has been found to increase lower root zone soil water $\mathrm{N}$ leaching at some sites. Harvesting may cause a small, short-lived increase in $\mathrm{N}$ leaching. Leaching may increase where residue is burned or heaped in mounds. Leaching increases if weed growth after harvest is inhibited or controlled using herbicide.

Overall, planted forests leach less $\mathrm{N}$ than other major land uses but there are key times during the forest cycle when $\mathrm{N}$ leaching may occur, particularly in forest planted on fertile pasture land. Measures to reduce $\mathrm{N}$ leaching losses in forests include minimising vegetation control at planting, maximising tree $\mathrm{N}$ uptake by correcting other growth-limiting factors, facilitating rapid site revegetation after harvesting, avoiding harvesting in winter/early spring, and applying fertiliser to coastal sands or other sites prone to high $\mathrm{N}$ leaching in small, but frequent, doses.

Forests may be planted specifically to reduce $\mathrm{N}$ losses to sensitive waterways in catchments with high $\mathrm{N}$ soils. However, leaching may still occur during the time between canopy closure and harvest. Nitrification inhibitors may have a role in reducing leaching in such instances. Fast-growing short-rotation tree crops have a continuously high demand for soil $\mathrm{N}$ so maybe useful in areas where there is a strong need to reduce $\mathrm{N}$ leaching caused by intensive agriculture. Modelling of nutrientbalances can assist in identifying and optimising the effect of suitable management practices on soil $\mathrm{N}$.

\section{Additional file}

\begin{abstract}
Additional file 1: Table S1. Nitrogen concentrations and leaching losses in streams from New Zealand native forests. Total stream-water $\mathrm{N}$ leaching loss is the sum of all the individual types of $\mathrm{N}$ shown, unless otherwise indicated. Table S2. Nitrogen concentrations and leaching loss in streams (and some springs) from plantation forests in New Zealand. Plantations are planted with Pinus radiata unless stated otherwise. Total stream-water $\mathrm{N}$ leaching loss is the sum of all the individual types of $\mathrm{N}$ shown, unless otherwise indicated. Table S3. Soil water nitrogen concentrations and estimated nitrogen leaching from the lower root zone of plantation forests in New Zealand. All forests are Pinus radiata unless stated otherwise. Forests are at least second rotation and are assumed to have been planted on land that has had little or no agricultural improvement. Nitrogen leaching from the lower root zone is the sum of the forms shown, or as indicated in the lower root zone leaching column. Table S4. Soil water nitrogen concentrations and estimated nitrogen leaching from the lower root zone of plantation forests in New Zealand. All forests are Pinus radiata and planted on land that was previously fertilised pasture and, except where stated, are first rotation. Lower root zone $\mathrm{N}$ leaching is the sum of the forms shown, or as indicated in the lower root zone leaching column.
\end{abstract}

\section{Competing interests}

The author declares that he has no competing interests.

\section{Acknowledgements}

This research was supported by the New Zealand Foundation for Research, Science and Technology through the Future Forest Research Programme "Protecting and Enhancing the Environment through Forestry" (Contract C04X0806). John Quinn, NIWA, is thanked for providing the data for Figure 1.

Received: 28 June 2013 Accepted: 5 December 2013

Published: 10 Jan 2014

\section{References}

Baker, TG, Oliver, GR, \& Hodgkiss, PD. (1986). Distribution and cycling of nutrients in Pinus radiata as affected by past lupin growth and fertiliser. Forest Ecology and Management, 17, 169-187.

Beets, PN, \& Brownlie, RK. (1987). Puruki experimental catchment: site, climate, forest management and research. New Zealand Journal of Forestry Science, 17, 137-160.

Beets, P, Gilchrist, K, \& Jeffreys, M. (2001). Wood density of radiata pine: effect of nitrogen supply. Forest Ecology and Management, 145, 173-180.

Binkley, D, Burnham, H, \& Allen, H. (1999). Water impacts of forest fertilisation with nitrogen and phosphorus. Forest Ecology and Management, 121, $191-213$.

Cameron, KC, Di, HJ, \& Moir, JL. (2013). Nitrogen losses from the soil/plant system: a review. Annals of Applied Biology, 162, 145-173.

Collier, KJ, \& Bowman, EJ. (2003). Role of wood in pumice-bed streams I: impacts of post-harvest management on water quality, habitat and benthic invertebrates. Forest Ecology and Management, 177, 243-259.

Compton, JE, Church, MR, Larned, ST, \& Hogsett, WE. (2003). Nitrogen export from forested watersheds in the oregon coast range: the role of $\mathrm{N}_{2}$-fixing red alder. Ecosystems, 6, 773-785.

Cooper, AB. (1986). Suppression of nitrate formation within an exotic conifer plantation. Plant and Soil, 93, 383-394.

Cooper, AB, Hewitt, JE, \& Cooke, JG. (1987). Land use impacts on streamwater nitrogen and phosphorus. New Zealand Journal of Forestry Science, 17(2/3), 179-192. 
Cooper, BA, \& Thomsen, CE. (1988). Nitrogen and phosphorus in streamwaters from adjacent pasture, pine, and native forest catchments. New Zealand Journal of Marine and Freshwater Research, 22, 279-291.

Davis, MR. (1990). Chemical composition of soil solutions extracted from New Zealand beech forests and West German beech and spruce forests. Plant and Soil, 126, 237-246.

Davis, M, Coker, G, Watt, M, Graham, D, Pearce, S, \& Dando, J. (2012). Nitrogen leaching after fertilising young Pinus radiata plantations in New Zealand. Forest Ecology and Management, 280, 20-30.

Di, HJ, \& Cameron, KC. (2002). Nitrate leaching in temperate agroecosystems: sources, factors and mitigating strategies. Nutrient Cycling in Agroecosystems, 64, 237-256.

Duggan, IC, Collier, KJ, Champion, PD, Croker, GF, Davies-Colley, RJ, Lambert, PW, Nagels, JW, \& Wilcock, RJ. (2002). Ecoregional differences in macrophyte and macroinvertebrate communities between Westland and Waikato: are all New Zealand lowland streams the same? New Zealand Journal of Marine and Freshwater Research, 36(4), 831-845.

Dyck, WJ, Webber, BD, \& Barton, PG. (1981). Soil-water nutrient concentrations after clearfelling and burning of Pinus radiata. New Zealand Journal of Forestry Science, 11, 128-144.

Dyck, WJ, Gosz, JR, \& Hodgkiss, PD. (1983). Nitrate losses from disturbed ecosystems in New Zealand - a comparative analysis. New Zealand Journal of Forestry Science, 13(1), 14-24.

Dyck, WJ, Mees, CA, \& Hodgkiss, PD. (1987). Nitrogen availability and comparison to uptake in two New Zealand Pinus radiata forests. New Zealand Journal of Forestry Science, 17, 338-352.

Elliot, AH, Alexander, RB, Schartz, GE, Shanker, U, Sukias, JP, \& McBride, GB. (2005). Estimation of nutrient sources and transport for New Zealand using the hybrid mechanistic-statistical model SPARROW. Journal of Hydrology (New Zealand), 44, 1-27.

Fahey, B, \& Jackson, R. (1997). Environmental effects of forestry at big bush forest, South Island, New Zealand. Journal of Hydrology (New Zealand), 36(1), 43-71.

Fahey, B, \& Stansfield, B. (2006). Forestry effects on water quality. In G Eyles \& B Fahey (Eds.), The Pakuratahi Land Use Study (pp. 63-73). http://www.hbrc. govt.nz/Services/Environment/Land/Resources and Publications. Accessed 19 March 2013.

Gundersen, P, Schmidt, IK, \& Raulund-Rasmussen, K. (2006). Leaching of nitrate from temperate forests-effects of air pollution and forest management. Environmental Reviews, 14, 1-57.

Hamilton, D. (2005). Land use impacts on nutrient export in the central volcanic plateau, North Island. New Zealand Journal of Forestry, 49(4), 27-31.

Hedin, LO, Armesto, JJ, \& Johnson, AH. (1995). Patterns of nutrient loss from unpolluted old-growth temperate forests: evaluation of biogeochemical theory. Ecology, 76, 223-235.

Hewitt, AE. (1992). New Zealand Soil Classification: (D. S. I. R. Land Source Scientific Report No. 19). Lower Hutt, New Zealand: DSIR Land Resources.

Kortelainen, P, Mattsson, T, Finer, L, Ahtiainen, M, Saukkonen, S, \& Sallantaus, T. (2006). Controls on the export of C, N, P and Fe from undisturbed boreal catchments, Finland. Aquatic Sciences, 68, 453-468.

Knight, P, \& Will, G. (1977). A field lysimeter to study water movement and nutrient content in a pumice soil under Pinus radiata forest. 2: deep seepage and nutrient leaching in the first 12 years of growth. New Zealand Journal of Forestry Science, 7, 274-296.

Larned, ST, Scarsbrook, MR, Snelder, TH, Norton, NJ, \& Biggs, JF. (2004). Water quality in low elevation streams and rivers of New Zealand: recent state and trends contrasting land-cover classes. New Zealand Journal of Marine and Freshwater Research, 38, 347-366.

Leonard, JH. (1977). Nitrogen run-off from a radiata pine forest fertilised with urea. New Zealand Journal of Forestry, 22(1), 64-80

Lewis, WM. (2002). Yield of nitrogen from minimally disturbed watersheds of the United States. Biogeochemistry, 57, 375-385.

Magesan, GN, Wang, H, \& Clinton, PW. (2012). Nitrogen cycling in gorsedominated ecosystems in New Zealand. New Zealand Journal of Ecology, 36(1), 21-28

McColl, RHS, White, E, \& Gibson, AR. (1977). Phosphorus and nitrate run-off in hill pasture and forest catchments, Taita, New Zealand. New Zealand Journal of Marine and Freshwater Research, 11(4), 729-744.

McGroddy, ME, Baisden, WT, \& Hedin, LO. (2008). Stoichiometry of hydrological C, $\mathrm{N}$ and $\mathrm{P}$ losses across climate and geology: an environmental matrix approach across New Zealand primary forests. Global Biogeochemical Cycles, 22(1), GB1026. doi:10.1029/2007GB003005
Ministry for the Environment. (2010). Land Use Environmental Snapshot: environmental report card 2010. Wellington, New Zealand. Available at http:// www.mfe.govt.nz/environmental-reporting/land/land-use-indicator/land-useenvironmental-snapshot.html. Accessed 21 Oct 2013.

Ministry of Health. (2008). Drinking water standards for New Zealand 2005 (Revised 2008). Wellington, New Zealand. Accessed 13 Nov 2013.

Molloy, L. (1998). Soils in the New Zealand Landscape: the Living Mantle (2nd ed.). Lincoln, New Zealand: New Zealand Society of Soil Science.

Mosley, MP, \& Rowe, LK. (1981). Low flow water chemistry in forested and pasture catchments, Mawheraiti River, Westland. New Zealand Journal of Marine and Freshwater Research, 15, 307-320.

Ministry for Primary Industries. (2012). National Exotic Forest Description. Wellington, New Zealand. Available at http://www.mpi.govt.nz/newsresources/statistics-forecasting/statistical-publications/national-exotic-forestdescription. Accessed 21 October 2013.

Neary, DG, \& Leonard, JH. (1978). Effects of forest fertilisation on nutrient losses in streamflow in New Zealand. New Zealand Journal of Forestry Science, 8(1), 189-205.

Neary, D, Pearce, A, O'Loughlin, C, \& Rowe, L. (1978). Management impacts on nutrient fluxes in beech-podocarp-hardwood forests. New Zealand Journal of Ecology, 1, 19-26.

O'Loughlin, CL, Rowe, LK, \& Pearce, AJ. (1980). Sediment yield and water quality responses to clearfelling of evergreen mixed forests in Western New Zealand. In The influence of man on the hydrological regime with special reference to representative and experimental basins: proceedings of the Helsinki Symposium June 1980 (pp. 285-292). International Association of Hydrological Sciences publication no. 130

Parfitt, RL, Hill, LF, \& Scott, NA. (1997a). Does contact of Pinus radiata slash with soil influence post-harvest nutrient losses? New Zealand Journal of Forestry Science, 27, 174-187.

Parfitt, RL, Percival, HJ, Dahlgren, RA, \& Hill, LF. (1997b). Soil and soil solution chemistry under pasture and radiata pine in New Zealand. Plant and Soil, 91, 279-290.

Parfitt, RL, Salt, GJ, \& Hill, LF. (2002). Clear-cutting reduces nitrate leaching in a pine plantation of high natural $\mathrm{N}$ status. Forest Ecology and Management, $170,43-53$

Parfitt, RL, Ross, DJ, \& Hill, LF. (2003a). Soil nitrogen mineralization changes rapidly when pine is planted in pasture - the first two years of growth. Australian Journal of Soil Research, 41, 459-469.

Parfitt, RL, Scott, NA, Ross, DJ, Salt, GJ, \& Tate, KR. (2003b). Land-use change effects on soil $C$ and $N$ transformations in soils of high $N$ status: comparisons under indigenous forest, pine plantation and pasture. Biogeochemistry, 66, 203-221.

Parfitt, RL, \& Ross, DJ. (2011). Long-term effects of afforestation with Pinus radiata on soil carbon, nitrogen, and pH: a case study. Soil Research, 49, 494-503.

Perakis, SS, \& Hedin, LO. (2001). Fluxes and fates of nitrogen in soil of an unpolluted old-growth temperate forest southern Chile. Ecology, 82, $2245-2260$

Quinn, JM, \& Ritter, E. (2003). Effects of land use and pine forest logging on stream nutrients at Purukohukohu, Central North Island. In NC Miller \& EM Miller (Eds.), Rotorua Lakes 2003: Practical Management for Good Lake Water Quality, Proceedings and Report (pp. 149-157). Rotorua, New Zealand: Lakes Water Society.

Quinn, JM, \& Stroud, MJ. (2002). Water quality and sediment and nutrient export from New Zealand hill-land catchments of contrasting land use. New Zealand Journal of Marine and Freshwater Research, 36(2), 409-429.

Quinn, JM, Cooper, AB, Davies-Colley, RJ, Rutherford, JC, \& Williamson, RB. (1997) Land use effects on habitat, water quality, periphyton, and benthic invertebrates in Waikato, New Zealand, hill-country streams. New Zealand Journal of Marine and Freshwater Research, 31(5), 579-597.

Rolando, CA, Gous, SF, \& Watt, MS. (2011). Preliminary screening of herbicide mixes for the control of five major weed species on certified Pinus radiata plantations in New Zealand. New Zealand Journal of Forestry Science, 41, 165-175.

Rothe, A. (2005). Tree species management and nitrate contamination of groundwater: a central European perspective. In D Binkley \& O Menyailo (Eds.), Tree species effects on soils: Implications for global change (pp. 71-83). Netherlands: Springer.

Rowe, LK, \& Fahey, BD. (1991). Hydrology and water chemistry changes after harvesting small, indigenous forest catchments, Westland, New Zealand. In NE Peters \& DE Walling (Eds.), Stream and Stream Water Quality in a Changing Environment: trends and Explanation: proceedings of a Vienna 
Symposium, August 1991 (pp. 259-256). International Association of Hydrological Sciences Publication no. 203.

Smith, CT, Dyck, WJ, Beets, PN, Hodgkiss, PD, \& Lowe, AT. (1994). Nutrition and productivity of Pinus radiata following harvest and disturbance and fertilization of coastal sand dunes. Forest Ecology and Management, 66, 5-38 Smaill, SJ, Clinton, PW, \& Höck, B. (2011). A nutrient balance model (NuBalM) to predict biomass and nitrogen pools in Pinus radiata forests. Forest Ecology and Management, 262, 270-277.

Stenzel, A, \& Herrmann, R. (1990). Comparing the effects of acidic deposition on the chemistry of small streams in the South Island of New Zealand with those in the Fichtelgebirge Catena, 17(1), 69-83, F.R.G.

Thomas, RC, \& Mead, DJ. (1992). Uptake of nitrogen by Pinus radiata and retention within the soil after applying ${ }^{15} \mathrm{~N}$-labelled urea at different frequencies. 2: seasonal trends and processes. Forest Ecology and Management, 53, 153-174.

Vanderbilt, KL, Lajtha, K, \& Swanson, FJ. (2002). Biogeochemistry of unpolluted forested watersheds in the oregon cascades: temporal patterns of precipitation and stream nitrogen fluxes. Biogeochemistry, 62, 87-117.

Waikato Regional Council. (2012). 3.10 Lake Taupo Catchment. In Waikato Regional Plan (online version). Available at http://www.waikatoregion.govt.nz/ Council/Policy-and-plans/Rules-and-regulation/Regional-Plan/WaikatoRegional-Plan. Accessed 27 Oct 2013.

Wardle, P. (1991). Vegetation of New Zealand. New Jersey, USA: Blackburn Press.

Watson, A, Davie, T, Bowden, B, \& Payn, J. (2003). Biosolids Joint Research Programme: Joint Report For 2002-03 (Objective 3 - Fate and mobility of municipal biosolids constituents). Landcare Research Contract Report: LC0203/186.

West, GG. (1995). Oversowing in forests. In D Hammond (Ed.), NZIF 1995 Forestry Handbook (pp. 78-79). Christchurch, New Zealand: New Zealand Institute of Forestry (Inc).

West, GG, Percival, NS, \& Dean, MG. (1988). Oversowing legumes and grasses for forest grazing: interim research results. In Proceedings of the Agroforestry Symposium, Rotorua, New Zealand, 24-27 Nov 1986: (FRI Bulletin No. 139) (pp. 203-220). Rotorua, New Zealand: Forest Research Institute.

Williard, KWJ, DeWalle, DR, \& Edwards, PJ. (2005). Influence of bedrock geology and tree species composition on stream nitrate concentrations in midAppalachian forested watersheds. Water, Air and Soil Pollution, 160, 55-76.

Worsnop, G, \& Will, G. (1980). Fate of ${ }^{15} \mathrm{~N}$ urea fertiliser applied to a recently thinned radiata pine stand on a pumice soil. New Zealand Journal of Forestry Science, 10, 381-394.

Zabowski, D. (1989). Lysimeter and centrifuge soil solutions: a comparison of methods and objectives. In WJ Dyck \& CA Mees (Eds.), Research strategies of long-term site productivity: proceedings, IEABBE A3 Workshop, Seattle, WA, August 1988: (FRI Bulletin No. 152) (pp. 139-148). Rotorua, New Zealand: Forest Research Institute.

10.1186/1179-5395-44-2

Cite this article as: Davis: Nitrogen leaching losses from forests in New

Zealand. New Zealand Journal of Forestry Science 2014, 44:2

\section{Submit your manuscript to a SpringerOpen ${ }^{\odot}$ journal and benefit from:}

- Convenient online submission

- Rigorous peer review

- Immediate publication on acceptance

- Open access: articles freely available online

- High visibility within the field

- Retaining the copyright to your article

Submit your next manuscript at $>$ springeropen.com 